OPINION 22

Status of the Generic Name Asterococcus and Conservation of the Generic Name Mycoplasma

Species names that have been proposed for the organism of bovine pleuropneumonia are:

1. Asterococcus mycoides Borrel, Dujardin-Beaumetz, Jeantet and Jouan 1910 was validly published, but is a later homonym of Asterococcus Scherffel 1908 and hence illegitimate.

2. Coccobacillus mycoides peripneumoniae Martzinovski 1911 is a trinomial and hence illegitimate.

3. Micromyces peripneumoniae bovis contagiosae Frosch 1923. Micromyces Frosch is a later homonym of two validly published earlier generic names (Micromyces Dangeard 1889 and Micromyces Grüber 1891), and hence illegitimate.

4. Mycoplasma peripneumoniae Nowak 1929. The generic name was validly published and the older names were not available. The specific epithet is illegitimate and should be replaced with mycoides which has priority.

5. Asteromyces peripneumoniae bovis Wroblewski 1931. This combination was validly published, but both generic and specific names are later homonyms.

6. Anulomyces aga laxiae Wroblewski 1931. Proposed for the organism causing contagious agalactia in goats and sheep. validly published but only legitimate if this organism is considered as belonging to a different genus from the causal organism of bovine peripneumonia.

7. Borrelomyces peripneumoniae Turner 1935. Borrelomyces was validly published but is a later synonym of other generic names for the same organism.

Freundt (1955) and Edward (1955) put forward proposals for the classification of the pleuropneumonia group of organisms, and each recognized the validity of the generic name Mycoplasma. Later (1956) they jointly proposed a classifica$t$ ion and nomenclature which Freundt subsequently used in the 7 th edition of Bergey's Manual of Determinative Bacteriology. 
The following Opinion 22 was approved unanimously by the Judicial Commission and by the International Committee on Bacteriological Nomenclature at meetings held in August, 1958 in Stockholm in connection with the meeting of the VII International Microbiological Congress.

\section{Opinion 22}

1. The generic name Asterococcus Borrel, DujardinBeaumetz, Jeantet, and Jouan 1910 is a later homonym of Asterococcus Scherffel 1908, and hence illegitimate.

2. The generic name Mycoplasma Nowak 1929 is placed in the list of bacterial nomina generum conservanda as the first legitimate generic name proposed to replace Asterococcus Borrel et al. The type species is Mycoplasma mycoides (Borrel et al.) Freundt 1955 (basonym Asterococcus mycoides Borrel et $\underline{\text { al. }}$.).

\section{REFERENCES}

Borrel, Dujardin-Beaumetz, Jeantet and Jouan. 1910. Le mi crobe de las peripneumonie. Ann. Inst. Past. 244:168.

Dangeard, P.A. 1889. Memoire sur les Chytridinées. Le Botaniste $4: 39-74$.

Editorial Board. 1955. The status and synonymy of the bacterial generic name Asteroc œcus. Internatl. Bull. Bact. Nomen. Tax. 5:13-20.

Edward, D.G. 1955. A suggested classification and nomenclature for organisms of the pleuropneumonia group. Internatl. Bull. Bact. Nomen. Tax. 5:85-94.

and E.A. Freundt. 1956. The classification and nomenclature of organisms of the pleuropneumonia group. Jour. Gen. Microbiol. 14:197.

Freundt, E.A. 1955. The classification of the pleuropneumonia group of organisms. Internatl. Buil. Bact. Nomen. Tax. $\underline{5}: 67-78$.

Frosch, P. 1923. Zur Morphologie des Lungenseucheerregers. II. Mit Arch. wiss. u. prakt. Tierheilkunde 49:273-282.

Grüber, M. 1891. Micromyces hoffmannii. Centr. f. Bakt. 10: 648 . 
Martzinovski, E.J. 1911. De l'etiologie de la péripneumonie. Ann. Inst. Past. 25:914-917.

Nowak, Julien 1929. Morphologie, nature et cycle évolutif du microbe de la péripneumonie des bovides. Ann. Inst. past. 43:1330-1352.

Sabin, Albert B. 1941. The filtrable microorganisms of the pleuropneumonia group. Bact. Revs. 5:1-68.

Scherffel, A. 1908. Asterococcus n.g. superbus (Cienk.) Scherffel and dessen angebliche Bezeichnungen zu Eremosphaera. Ber. deutsch. bot. Ges. 26A:762-771.

Turner, A.W. 1935. A study of the morphology and life cycles of the organism of pleuropneumonia contagiosa boum (Borrelomyces peripneumoniae nov. gen.) by observation in the living state under dark-ground illumination. Jour. Path. Bact. 41:1-32.

Wroblewski, W. 1931. Morphologie et cycle évolutif des microbes de la péripneumonie des bovides et de l'agalaxie contagieuse des chevres et des moutons. Ann. Inst. Past. 47:94-116. 